\title{
Berhukum Secara Objektif Pada Kasus Baiq Nuril: Suatu Telaah Filsafat Hukum Melalui Kajian Paradigmatik
}

\author{
Aditya Yuli Sulistyawan \\ Fakultas Hukum Universitas Diponegoro Semarang \\ adityayuli38@gmail.com
}

\begin{abstract}
ABSTRAK
Belakangan ini. kasus Baiq Nuril benar-benar menyita perhatian publik. Kasus hukum ini bermula saat Nuril yang saat itu masih bekerja sebagai pegawai honorer di SMAN 17 Mataram, merekam percakapan telepon Kepala Sekolah kepadanya yang berkonten kesusilaan dan bernada melecehkan dirinya. Singkat cerita, melalui rekannya, rekaman pembicaraan tersebut tersebar. Nuril pun dilaporkan atas sangkaan Pasal 27 (1) Undang-Undang Informasi dan Transaksi Elektronik (ITE). Proses hukum bergulir, Pengadilan Negeri Mataram memberikan vonis bebas kepada Nuril. Namun, Penuntut Umum mengajukan kasasi dan Mahkamah Agung akhirnya memvonis Nuril bersalah dengan hukuman pidana penjara 6 bulan kurungan dan denda lima ratus juta rupiah. Inilah yang kemudian memunculkan polemik. Masyarakat memprotes putusan yang dianggapnya tidak adil tersebut. Kekecewaan masyarakat kepada hukum sangat terasa melalui berbagai gerakan untuk membela Nuril, baik melalui penggalangan dana maupun aksi demonstrasi. Mereka kecewa kepada hukum yang nyatanya malah memberi hukuman pada seorang korban pelecehan seksual. Berbagai persepsi buruk terhadap hukum bermunculan, masyarakat ramai memberi pandangan awam mereka terhadap kasus ini. Secara ilmiah, kasus ini semestinya dapat diuraikan dengan jelas melalui ilmu hukum, terlebih melalui filsafat hukum. Adalah tugas kita sebagai akademisi untuk menguraikan setiap duduk peristiwa kasus menjadi lebih terang, agar tidak menimbulkan kesesatan berpikir di masyarakat. Berdasarkan uraian ini, penulis akan menjawab permasalahan mengenai bagaimanakah cara berhukum objektif yang diterapkan dalam kasus ini, serta bagaimana telaah filsafat hukum melalui kajian paradigma akan menguraikan persoalan hukum ini. Pembahasan akan dijabarkan dalam paradigma penulis yakni paradigma konstruktivisme dan melalui metode hermenutikal/dialektikal.
\end{abstract}

Kata Kunci: objektif; Baiq Nuril; filsafat hukum; paradigma.

\begin{abstract}
Recently, the Baiq Nuril case really caught the public's attention. This legal case began when Nuril, who at that time was still working as a temporary employee at the SMAN 17 Mataram, recorded the principal's telephone conversation with him who was in decency and insulted him. Long story short, through his colleague, the recording of the conversation was spread. Nuril was reported on the suspicion of Article 27 (1) of the Electronic Information and Transaction Law (ITE). The legal process was rolling, the Mataram District Court gave Nuril a free verdict. However, the Public Prosecutor filed an appeal and the Supreme Court finally sentenced Nuril guilty to a sentence of 6 months imprisonment and a fine of five hundred million rupiah. This is what later led to the polemic. The community protested the decision which he considered unfair. The people's disappointment in the law was felt through various
\end{abstract}


movements to defend Nuril, both through fundraising and demonstrations. They are disappointed in the law which in fact actually punishes a victim of sexual abuse. Various bad perceptions of the law have sprung up, people are busy giving their lay views on this case. Scientifically, this case should be clearly explained through legal science, especially through legal philosophy. It is our duty as academics to elaborate on each sitting the case of the case becomes brighter, so as not to cause an error in thinking in society. Based on this description, the author will answer the problem of how the objective legal method applied in this case, and how the study of legal philosophy through the study of paradigms will describe this legal issue. The discussion will be elaborated in the author's paradigm of the constructivism paradigm and through the hermenutical / dialectical method.

Keyword: objective; Baiq Nuril; philosophy of law; paradigm.

\section{PENDAHULUAN}

Perhatian publik saat ini sedang tertuju kepada satu kasus hukum yang tengah disorot secara masif oleh media masa. Baiq Nuril, nama perempuan ini belakangan menjadi sangat terkenal di kalangan masyarakat luas, karena ironi yang menimpanya akibat penjatuhan vonis kasasi Mahkamah Agung No. 574K/Pid.Sus/2018 yang petikannya berbunyi: ${ }^{1}$

Menyatakan Baiq Nuril bersalah melakukan tindak pidana, tanpa hak mendistribusikan dan/atau mentransmisikan dan/atau membuat dapat diaksesnya informasi elektronik dan/atau dokumen elektronik yang memiliki muatan yang melanggar kesusilaan. Menjatuhkan pidana kepada Terdakwa oleh karena itu dengan pidana penjara selama 6 (enam) bulan dan pidana denda sejumlah $R p$ 500.000.000,00 (lima ratus juta rupiah) dengan ketentuan apabila pidana denda tersebut tidak dibayar maka diganti dengan pidana kurungan selama 3 (tiga) bulan.

Demikianlah vonis yang dianggap menggegerkan dunia penegakan hukum itu. Sekian banyak gelombang protes bermunculan atas kasus yang dianggap tidak adil bagi Baiq Nuril. Tidak kurang aksi-aksi demonstrasi dan penggalangan dana dilakukan sebagai bentuk simpati atas apa yang terjadi kepada seorang perempuan yang bernama Baiq Nuril tersebut. Media massa aktif menyorot kasus itu, para pakar bermunculan khususnya di televisi, mengomentari penegakan hukum yang dianggap justru telah salah menghukum Baiq Nuril yang sejatinya adalah korban pelecehan seksual yang dilakukan oleh atasannya yakni Kepala Sekolah SMAN 17 Mataram, melalui percakapan via telepon tersebut.

Kasus ini sendiri bermula ketika Baiq Nuril masih bekerja sebagai tenaga honorer di SMAN 17 Mataram. Saat itu, pertengahan tahun 2012 Baiq Nuril ditelepon oleh M, Kepala

\footnotetext{
${ }^{1}$ Juli Hantoro, "ICJR Pertanyakan Putusan MA dalam Kasus Baiq Nuril”, Tempo.Co, diakses dari https://nasional.tempo.co/read/1146060/icjr-pertanyakan-putusan-ma-dalam-kasus-baiq-nuril, pada tanggal 14 November 2018.
} 
Sekolah SMAN 17 Mataram. Perbincangan antara M dan Baiq Nuril berlangsung selama kurang lebih 20 menit. Dari 20 menit perbincangan itu, hanya sekitar 5 menit saja yang membicarakan soal pekerjaan. Sisanya, M malah bercerita soal pengalaman seksualnya bersama dengan wanita yang bukan istrinya. Perbincangan itu pun terus berlanjut dengan nada-nada pelecehan terhadap Baiq Nuril. ${ }^{2}$ Singkat cerita, Baiq Nuril yang merasa tidak nyaman kemudian merekam percakapan telepon atasannya tersebut. Akhirnya rekaman tersebut bocor dan tersebar melalui rekan Baiq Nuril yang bernama Imam Mudawin, karena cerita dan rekaman yang ditunjukkan sebelumnya oleh Baiq kepada Imam. Disinilah persoalan hukum bermula, Baiq Nuril dilaporkan oleh M kepada polisi atas tuduhan Pasal 27 (1) Undang-Undang Informasi dan Transaksi Elektronik. Putusan bebas yang sempat dijatuhkan Pengadilan Negeri Mataram kepada Nuril berlanjut hingga kasasi yang diajukan oleh Jaksa Penuntut Umum, hingga kemudian Baiq Nuril dinyatakan bersalah oleh majelis hakim tingkat kasasi di Mahkamah Agung.

Putusan ini lantas menuai kritik. Dalam rilis resminya, Institute for Criminal Justice Reform (ICJR) menyebut hakim seharusnya berpedoman pada Peraturan Mahkamah Agung (Perma) Nomor 3 tahun 2017 tentang Pedoman Mengadili Perempuan Berhadapan dengan Hukum. Pasal 3 huruf $\mathrm{b}$ Perma tersebut menyebutkan hakim mengidentifikasi situasi perlakuan tidak setara yang diterima perempuan yang berhadapan dengan hukum. ${ }^{3}$

Kecaman dan aksi protes terhadap putusan kasasi yang dijatuhkan Mahkamah Konstitusi terhadap Baiq Nuril terlanjur menjadi "bola panas". Masyarakat awam bahkan dengan mudahnya memberi cap “tidak adilnya hukum kepada orang yang lemah”. Berbagai persepsi pun bermunculan, wajar karena media massa memperlihatkan bagaimana kemudian Baiq Nuril justru kehilangan pekerjaannya, sementara M, mantan Kepala Sekolah SMAN 17 Mataram tersebut menikmati kenaikan pangkatnya sebagai aparatur sipil negara di Dinas Pemuda dan Olahraga setempat. Media massa sekali lagi menyajikan kasus ini dengan "bumbu-bumbu" drama yang kian memanaskan keadaan dan memancing kekecewaan publik.

Dari realitas yang berkembang saat ini, setidaknya penulis dapat memberikan simpulan senada tentang bagaimana "duduk peristiwa" ini terpahami oleh publik. Publik sepertinya

\footnotetext{
${ }^{2}$ SAH dan ARH, "Kronologi Kasus Baiq Nuril", CNN Indonesia, diakses dari https://www.cnnindonesia.com/nasional/20181114133306-12-346485/kronologi-kasus-baiq-nuril-bermula-daripercakapan-telepon, pada tanggal 14 November 2018. ${ }^{3}$ Ibid.
} 
kian memberi label negatif terhadap hukum, tanpa pemahaman yang baik. Hal inilah yang kemudian melatarbelakangi penulis untuk melakukan penelitian terhadap kasus ini secara ilmiah karena kita tidak bisa membiarkan setiap prasangka yang bermodalkan pembenaran kepada persepsi semata. Adalah tugas penulis, selaku akademisi yang berkecimpung di dunia ilmu hukum, terlebih lagi sebagai pengajar pada mata kuliah Filsafat Hukum, untuk memberikan pencerahan melalui dunia akademis tentang apakah itu kebenaran hukum, juga keadilan melalui media jurnal ilmiah ini, bukan juga artikel teks di media massa, semata-mata hanya ingin menjaga sifat ilmiahnya itu sendiri agar uraian ini benar-benar bersifat akademis.

Berbeda dengan teori hukum, ilmu hukum memberi penekanan pada segi bentuk, sedangkan filsafat hukum memberi penekanan pada substansi atau isi. ${ }^{4} \mathrm{Hal}$ ini berarti bahwa filsafat hukum akan mampu menelaah sampai ke level hakikat dari hukum, menjawab tentang kaitannya dengan hal-hal yang mendasar, seperti keadilan dan nilai-nilai daripada hukum. Telaah filsafat hukum memungkinkan penulis untuk menguraikan permasalahan kasus Baiq Nuril ini secara komprehensif, jelas, dan detail sampai kepada penjelasan ontologis, epistemologis, dan metodologis. Hal ini dikarenakan penulis menggunakan pisau analisis paradigma sebagai sistem filsafat induk yang memungkinkan melakukan telaah sampai ke level tersebut.

Berdasarkan uraian latar belakang yang telah disampaikan, penulis dalam paper ini akan menjawab permasalahan mengenai: a) Bagaimanakah cara berhukum yang diterapkan oleh Mahkamah Agung dalam kasus Baiq Nuril ini?, dan b) Bagaimanakah telaah filsafat hukum melalui kajian paradigma akan menguraikan persoalan hukum ini? Sementara itu, paper ini bertujuan untuk memberikan penjelasan secara ilmiah dalam telaah filsafat hukum khususnya agar memberikan kontribusi pemahaman kepada masyarakat luas mengenai kasus yang dihadapi oleh Baiq Nuril.

\section{METODE PENELITIAN}

Sebagai akuntabilitas ilmiah, setiap peneliti ataupun penulis harus mampu memaparkan setiap proses penelitian yang memandu jalan penelitian, penulisan, dan penuangan setiap hasil pemikirannya. Begitu-pun dalam paper ini, penulis bertanggung-jawab untuk menyebutkan

\footnotetext{
${ }^{4}$ Dominikus Rato, Filsafat Hukum: Mencari, Menemukan, dan Memahami Hukum (Yogyakarta: LaksBang Justitia, 2010), 14.
} 
setiap proses penelitian dan penulisan yang memandu giat penulis dalam menghasilkan karya tulis ini.

Tradisi penelitian (yang berbicara mengenai standpoint atau titik pandang peneliti terhadap objek penelitian) yang digunakan penulis dalam paper ini adalah tradisi kualitatif. Menurut Kirk dan Miller sebagaimana dikutip oleh Lexy J. Moleong, istilah penelitian kualitatif pada mulanya bersumber pada pengamatan kualitatif yang dipertentangkan dengan pengamatan kuantitatif. ${ }^{5}$

Sementara itu, berdasarkan gagasan paradigma Guba dan Lincoln, dalam penulisan ini, penulis menggunakan paradigma konstruktivisme sebagai 'pisau analisis'. Adapun jawaban atas pertanyaan ontologis dari paradigma konstruktivisme adalah relativisme, jawaban atas pertanyaan epistemologis dari paradigma ini adalah transaksional/subjektif, serta jawaban atas pertanyaan metodologis dari paradigma ini adalah hermeneutikal/dialektikal. ${ }^{6}$

\section{HASIL DAN PEMBAHASAN}

\section{A. Cara Berhukum yang Diterapkan oleh Hakim Mahkamah Agung dalam Kasus Baiq Nuril}

Penegakan hukum yang dilakukan dalam kasus hukum Baiq Nuril terlihat pada dua tahap pemeriksaan perkara pada tingkat pertama oleh Pengadilan Negeri Mataram yang memutuskan vonis bebas kepada Baiq Nuril, dan pemeriksaan perkara pada tingkat kasasi oleh Mahkamah Agung yang berujung pada vonis bersalah dengan hukuman pidana sebagaimana sudah disebutkan di atas. Paper ini akan menentukan ruang lingkupnya pada pembahasan mengenai pemeriksaan perkara pada tingkat kasasi yang menghasilkan Putusan Mahkamah Agung No. 574K/Pid.Sus/2018 karena memang pada putusan inilah masyarakat ramai-ramai menyatakan kekecewaannya mengenai cara berhukum yang dilakukan oleh Majelis Hakim yang memeriksa perkara di Mahkamah Agung tersebut.

Pandangan, pendapat, ataupun pemikiran boleh saja berbeda. Namun, jika kita memberikan pandangan terhadap suatu kasus hukum hendaknya dilakukan atas dasar ilmu dan pengetahuan yang memadai tentang hukum. Sebaliknya, pendapat yang tidak didasarkan

\footnotetext{
5 Kirk dan Miller dalam Lexy J. Moleong, Metodologi Penelitian Kualitatif, (Bandung: Remaja Rosdakarya, 2007), 2.

${ }^{6}$ Egon G. Guba \& Yvonna S. Lincoln dalam Norman K. Denzin \& Yvonna S. Lincoln (ed), The Sage Handbook of Qualitative Research 1 Third Edition (Yogyakarta: Pustaka Pelajar, 2011), 209.
} 
atas ilmu, teori, dan filsafatnya, hanya akan menghasilkan pembenaran-pembenaran akibat kesesatan berpikir.

Sejatinya, putusan hakim pada tingkat kasasi terhadap Baiq Nuril bukanlah sesuatu yang salah dalam cara berhukum seorang hakim. Dalam khasanah aliran filsafat hukum, cara berpikir demikian terjabar melalui mahzab atau aliran Positivisme Hukum atau Legal Positivism. Hal ini berarti, hakim yang memeriksa perkara Baiq Nurul di tingkat kasasi tersebut bisa kita identifikasi sebagai penganut aliran tersebut. Mereka melakukan telaah dalam hakikat hukum atau kebenaran hukum yang tekstual. Sebuah pola berpikir kebenaran terhadap realitas hukum yang sah-sah saja diterapkan oleh seorang hakim.

Aliran positivisme hukum ini tidak bisa dilepaskan dari sumbangsih pemikiran John Austin, seorang ahli hukum dari Inggris. John Austin sangat dikenal sebagai pembangun teori hukum positif. Bahkan John Austin adalah ahli hukum yang pertama kali memperkenalkan positivisme hukum. Pemikiran hukumnya yang sangat terkenal adalah, bahwa yang disebut sebagai hukum yang berlaku (hukum positif) harus dipisahkan dari moral. Dengan mendasarkan pada keyakinannya tentang filsafat positivisme, John Austin menyatakan bahwa yang disebut hukum positif harus mengandung tiga karakter sebagai berikut: Pertama, hukum adalah perintah dari penguasa yang berdaulat; Kedua, perintah tersebut disertai ancaman dan sanksi; Ketiga, otoritas tersebut tidak tunduk pada siapapun, tetapi ditaati masyarakat. ${ }^{7}$

Senada, Hans Kelsen menyebutkan bahwa positivisme hukum menganggap pembicaraan moral, nilai-nilai telah selesai dan final manakala sampai pada pembentukan hukum positif. Oleh karena itulah penggalan kata-kata yang sangat terkenal dari Hans Kelsen: hukum ditaati bukan karena dinilai baik atau adil, tetapi karena hukum itu telah ditulis dan disahkan penguasa. Inilah salah satu teori yang diperkenalkan Hans Kelsen dengan nama Teori Hukum Murni. $^{8}$

Positivisme secara implisit hanya mereduksi ilmu pengetahuan pada ilmu-ilmu pasti (eksakta) dan secara vulgar mempertahankan status quo ilmu-ilmu sains yang hebat dan kredibel. Sementara itu, pemeriksaan terhadap pengetahuan lainnya seperti refleksi kritis

\footnotetext{
${ }^{7}$ Adji Samekto, Pergeseran Pemikiran Hukum dari Era Yunani Menuju Postmodernisme (Jakarta: Konstitusi Press, 2015), 73-74.

${ }^{8}$ Ibid, 79-80.
} 
pengetahuan humanis, jelas tidak ada dalam kamus positivisme. ${ }^{9}$ Konsep hukum yang dialirkan oleh positivisme hukum menampilkan sosok hukum yang sedemikian rupa objektif, tersedia dalam pemaknaan yang disampaikan oleh tulisan-tulisan peraturan sebagai objek yang independen. Hukum juga merupakan closed logical system, yang berarti peraturan dapat dideduksikan dari undang-undang yang berlaku tanpa perlu meminta bimbingan dari norma sosial, politik dan moral. ${ }^{10}$

Melihat pada kasus hukum Baiq Nuril, positivisme hukum sebagai dasar pemikiran kebenaran hakim yang memutus pada tingkat kasasi, memeriksa perkara ini atas dasar dakwaan yang diajukan oleh Jaksa Penuntut Umum, yakni Baiq Nuril yang didakwa atas Pasal 27 (1) Undang-Undang No. 11 Tahun 2008 tentang Informasi dan Transaksi Elektronik (selanjutnya disebut UU ITE), yang berbunyi: "Setiap orang dengan sengaja dan tanpa hak mendistribusikan dan/atau mentransmisikan dan/atau membuat dapat diaksesnya informasi elektronik dan/atau dokumen elektronik yang memiliki muatan yang melanggar kesusilaan.”

Secara normatif, hakim pada tingkat kasasi melihat bahwa unsur-unsur dalam pasal dakwaan tersebut terpenuhi dalam pemeriksaan di persidangan. Fakta-fakta empiris dapat menunjukkan secara sah dan meyakinkan bahwa Baiq Nuril melanggar Pasal 27 (1) UU ITE tersebut, yakni unsur: unsur setiap orang, unsur dengan sengaja dan tanpa hak mendistribusikan, serta unsur membuat dapat diaksesnya informasi elektronik dan/atau dokumen elektronik yang memiliki muatan yang melanggar kesusilaan. Jadi meskipun Baiq Nuril tidak menyebarkan sendiri konten rekaman tersebut, tindakannya menunjukkan rekaman tersebut kepada rekannya yang bernama Imam Mudawin, merupakan tindakan yang “dapat membuat dapat diaksesnya dokumen elektronik yang memiliki muatan yang melanggar kesusilaan" dalam pandangan positivisme hukum menurut teks-teks pasal tersebut.

Kasus hukum ini dalam telaah pendapat John Austin juga menunjukkan bahwa penegakan hukum sudah sesuai dengan tiga karakter hukum positif sebagaimana dijelaskan sebelumnya yakni: hukum adalah perintah dari penguasa yang berdaulat, perintah tersebut disertai ancaman dan sanksi, dan otoritas tersebut tidak tunduk pada siapapun, tetapi ditaati

\footnotetext{
${ }^{9}$ Teguh Prasetyo \& Abdul Halim Barkatullah, Filsafat, Teori, dan Ilmu Hukum: Pemikiran Menuju Masyarakat yang Berkeadilan dan Bermartabat (Jakarta: Rajagrafindo Persada, 2013), 182.

${ }^{10}$ Aditya Yuli Sulistyawan, "Mempersoalkan Objektivitas Hukum: Suatu Perbincangan Filsafat Hukum", (Jurnal Masalah-Masalah Hukum Vol. 41, No. 4, Tahun 2012), 508.
} 
masyarakat. Dalam analisis pemikiran Hukum Murni-nya Hans Kelsen, kasus ini juga harus dilihat sebagai implementasi positivisme hukum yang menganggap pembicaraan moral, nilainilai telah selesai dan final manakala sampai pada pembentukan hukum positif. Jadi UU ITE merupakan teks final yang harus diberlakukan secara objektif, sementara hal-hal terkait moral dan nilai harus dibuang jauh-jauh, karena kebenaran sudah tinggal diimplementasikan menurut teks, saat UU ITE sudah disahkan.

Pandangan publik terhadap kasus hukum Baiq Nuril pun melebar hingga konteks keadilan, yang mana publik melihat Baiq Nuril yang sejatinya adalah korban pelecehan seksual justru dinyatakan bersalah, namun pelaku yakni M, mantan Kepala Sekolah SMAN 7 Mataram justru melenggang bebas dan menikmati kenaikan jenjang jabatan dalam profesinya sebagai aparatur sipil negara. Dalam konteks ini, publik tidak memahami dengan baik bahwa hukum terikat dengan prosedur-prosedur sebagaimana yang disyaratkan oleh positivisme hukum. Publik seakan berharap hukum bisa memberi keadilan sebagaimana harapan mereka terhadap keadilan versi Tuhan, misalnya hukum diharapkan memberi keadilan untuk Baiq Nuril dan seharusnya menghukum M, mantan Kepala Sekolah SMAN 7 Mataram. Padahal, hukum dalam konteks ini terikat dengan teks, juga terikat dengan prosedur atau hukum acaranya. Jelas saja, hakim hanya akan memeriksa kasus hukum sebagaimana yang disodorkan dalam dakwaan Jaksa Penuntut Umum, tidak mungkin melebihi itu. Hakim juga hanya akan memeriksa kasus hukum yang didakwakan kepada Baiq Nuril, tidak mungkin melebihi itu atau tiba-tiba menghukum $\mathrm{M}$ dalam kasus hukum Baiq Nuril. Keadilan sebagaimana yang diharapkan publik niscaya akan terwujud jika M dilaporkan juga atas kasus pelecehan seksual kepada Baiq Nuril, tentu saja dalam berkas perkara yang lain (terpisah dari kasus Baiq Nuril). Sementara itu, dalam perkembangannya kondisi ini telah berlangsung, dimana M memang telah dilaporkan atas kasus hukum pelecehan seksual kepada Baiq Nuril. ${ }^{11}$ Tinggal kita tunggu saja kelanjutan proses hukum ini akan bergulir nantinya.

\section{B. Telaah Filsafat Hukum melalui Kajian Paradigma terhadap Kasus Hukum Baiq Nuril}

Dari awal penulis menjanjikan pembahasan terhadap kasus hukum Baiq Nuril secara padat, detail, dan komprehensif melalui telaah filsafat hukum dalam kajian paradigmatik. Maka dalam sub-bab ini penulis akan mulai menjelaskan dengan pemahaman tentang paradigma.

\footnotetext{
${ }^{11}$ Michael Hangga Wismabrata, "5 Fakta Baru Kasus Baiq Nuril: Muslim Tak Ngantor 4 Hari Hingga Nuril Diperiksa Polisi”, kompas.com, diakses dari https://regional.kompas.com/read/2018/11/24/14480891/5-faktabaru-kasus-baiq-nuril-muslim-tak-ngantor-4-hari-hingga-nuril pada tanggal 24 November 2018.
} 
Paradigma merupakan bagian daripada filsafat, karena ia merupakan filsafat utama, induk, atau 'payung' sebagaimana ditegaskan N.K. Denzin dan Y.S. Lincoln dalam pengertian paradigma, yakni: ${ }^{12}$

Paradigma adalah suatu sistem filosofis utama, induk, atau 'payung' yang terbangun dari ontologi, epistemologi, dan metodologi tertentu, yang masing-masingnya terdiri dari satu 'set' belief dasar atau worldview yang tidak dapat begitu saja dipertukarkan [dengan belief dasar atau worldview dari ontologi, epistemologi, dan metodologi paradigma lainnya]. Paradigma mem-presentasi- kan suatu sistem atau set belief 'dasar' tertentu yang berkenaan dengan prinsip-prinsip utama atau pertama, yang mengikatkan penganut/penggunanya pada world-view tertentu, berikut cara bagaimana 'dunia' harus dipahami dan dipelajari, serta yang senantiasa memandu setiap pikiran, sikap, kata, dan perbuatan penganutnya.

Dari sekian banyak pakar yang menawarkan pemahaman berikut klasifikasi paradigma, penulis cenderung mengadopsi pendapat Guba dan Lincoln yang menurut Erlyn Indarti lebih mencakup sekaligus sistematis, padat, dan rasional. Mereka, yang pada dasarnya lebih condong kepada pengertian global dari paradigma itu, membedakan paradigma berdasarkan pada jawaban masing-masing terhadap 3 (tiga) 'pertanyaan mendasar' yang menyangkut: ${ }^{13}$

a. bentuk dan sifat realitas, berikut apa yang dapat diketahui mengenai hal ini [disebut sebagai pertanyaan 'ontologis'];

b. sifat hubungan atau relasi antara individu atau kelompok masyarakat dengan lingkungan atau segala yang ada di luar diri-nya, termasuk apa yang dapat diketahui tentang hal ini [disebut sebagai pertanyaan 'epistemologis', ke dalam mana termasuk pula pertanyaan 'aksiologis']; dan

c. cara bagaimana individu atau kelompok masyarakat [tentunya termasuk peneliti] mendapatkan jawab atas apa yang ingin diketahuinya tersebut [disebut sebagai pertanyaan 'metodologis'].

Dalam konteks pengertian paradigma inilah, Guba dan Lincoln menawarkan 4 (empat) paradigma utama. Keempat paradigma dimaksud adalah : positivism; postpositivism; critical theory et al; dan constructivism. Keempat paradigma tersebut dibedakan satu sama lain melalui respon terhadap 3 (tiga) pertanyaan mendasar; yang meliputi pertanyaan 'ontologis', 'epistemologis', dan 'metodologis'. Berikut ini adalah 'Set Basic Belief dari keempat paradigma utama yang ditawarkan oleh Guba dan Lincoln tersebut: ${ }^{14}$

\section{Tabel 1. Set Basic Belief 4 (empat) Paradigma Utama}

\footnotetext{
${ }^{12}$ Erlyn Indarti, Diskresi dan Paradigma: Suatu Telaah Filsafat Hukum, Pidato Pengukuhan Guru Besar Universitas Diponegoro (Semarang: Badan Penerbit Undip, 2010).

${ }^{13}$ Ibid.

${ }^{14} \mathrm{Ibid}$.
} 


\begin{tabular}{|c|c|c|c|c|}
\hline Pertanyaan & Positivisme & Postpositivisme & Critical Theory et al & Konstruktivisme \\
\hline \multirow[b]{2}{*}{ Ontologi } & Realisme Naif : & Realisme Kritis: & Realisme Historis & Relativisme \\
\hline & $\begin{array}{l}\text { realitas } \\
\text { eksternal, } \\
\text { objektif, real, } \\
\text { dan dapat } \\
\text { dipahami. }\end{array}$ & $\begin{array}{c}\text { realitas } \\
\text { eksternal, } \\
\text { objektif, dan } \\
\text { real yang } \\
\text { dipahami scr } \\
\text { tidak } \\
\text { sempurna. }\end{array}$ & $\begin{array}{c}\text { realitas 'virtual' } \\
\text { yang terbentuk } \\
\text { oleh faktor sosial, } \\
\text { politik, budaya, } \\
\text { ekonomi, etnis, dan } \\
\text { 'gender'. }\end{array}$ & $\begin{array}{c}\text { realitas } \\
\text { majemuk \& be- } \\
\text { ragam, } \\
\text { berdasarkan } \\
\text { pengalaman } \\
\text { sosial- } \\
\text { individual, } \\
\text { lokal, dan } \\
\text { spesifik. }\end{array}$ \\
\hline \multirow[b]{3}{*}{ Epistemologi } & $\begin{array}{c}\text { Dualis / } \\
\text { Objektivis }\end{array}$ & Modifikasi & $\begin{array}{l}\text { Transaksional / } \\
\text { Subjektivis : }\end{array}$ & $\begin{array}{c}\text { Transaksional / } \\
\text { Subjektivis : }\end{array}$ \\
\hline & & Objektivis : & \multirow[b]{2}{*}{$\begin{array}{l}\text { peneliti dan objek } \\
\text { investigasi terkait } \\
\text { scr interaktif; } \\
\text { temuan di- } \\
\text { 'mediasi' oleh nilai } \\
\text { yang dipegang } \\
\text { semua pihak. }\end{array}$} & \multirow[b]{2}{*}{$\begin{array}{l}\text { peneliti dan } \\
\text { objek } \\
\text { investigasi } \\
\text { terkait secara } \\
\text { interaktif; } \\
\text { temuan di- } \\
\text { 'cipta'/ di- } \\
\text { 'konstruksi' } \\
\text { bersama. }\end{array}$} \\
\hline & $\begin{array}{c}\text { peneliti dan } \\
\text { objek investigasi } \\
\text { adalah dua entity } \\
\text { independen; } \\
\text { bebas nilai. }\end{array}$ & $\begin{array}{c}\text { dualisme surut } \\
\text { dan } \\
\text { objektivitas } \\
\text { menjadi } \\
\text { kriteria } \\
\text { penentu; } \\
\text { eksternal } \\
\text { objektivitas. }\end{array}$ & & \\
\hline \multirow[b]{2}{*}{ Metodologi } & $\begin{array}{l}\text { Eksperimental / } \\
\text { Manipulatif : }\end{array}$ & $\begin{array}{c}\text { Modifikasi } \\
\text { Eksperimental / } \\
\text { Manipulatif : }\end{array}$ & $\begin{array}{l}\text { Dialogis / } \\
\text { Dialektikal : }\end{array}$ & $\begin{array}{l}\text { Hermeneutikal } \\
\text { / Dialektikal : }\end{array}$ \\
\hline & $\begin{array}{c}\text { uji empiris dan } \\
\text { verifikasi } \\
\text { research } \\
\text { question dan } \\
\text { hipotesa; } \\
\text { manipulasi dan } \\
\text { kontrol terhadap } \\
\text { kondisi } \\
\text { berlawanan; } \\
\text { utamanya } \\
\text { metoda } \\
\text { kuantitatif. }\end{array}$ & $\begin{array}{c}\text { falsifikasi } \\
\text { dengan cara } \\
\text { critical } \\
\text { multiplism atau } \\
\text { modifikasi } \\
\text { 'triangulasi'; } \\
\text { utilisasi teknik } \\
\text { kualitatif: } \\
\text { setting lebih } \\
\text { natural, } \\
\text { informasi lebih } \\
\text { situasional, dan } \\
\text { cara pandang } \\
\text { emic. }\end{array}$ & $\begin{array}{c}\text { ada 'dialog' antara } \\
\text { peneliti dengan } \\
\text { objek investigasi, } \\
\text { bersifat dialektikal } \\
\text { : men-'transform' } \\
\text { kemasa-bodohan } \\
\text { dan kesalah- } \\
\text { pahaman menjadi } \\
\text { kesadaran untuk } \\
\text { mendobrak. }\end{array}$ & $\begin{array}{c}\text { 'konstruksi' } \\
\text { ditelusuri } \\
\text { melalui } \\
\text { interaksi antara } \\
\text { peneliti dan } \\
\text { objek } \\
\text { investigasi; } \\
\text { dengan teknik } \\
\text { hermeneutikal } \\
\text { dan pertukaran } \\
\text { dialektikal } \\
\text { 'konstruksi' di- } \\
\text { interpretasi; } \\
\text { tujuan : distilasi } \\
\text { / konsensus / } \\
\text { resultante. }\end{array}$ \\
\hline
\end{tabular}


Sumber : Guba dan Lincoln (1994)

Berdasarkan empat paradigma utama tersebut, akan terlihat jelas hakikat hukum terjabar secara berbeda pada masing-masing paradigma menurut ontologinya. Paradigma positivisme misalnya, hukum dimaknai sebagai realitas naif yaitu realitas eksternal, objektif, real, dan dapat dipahami. Dalam pemaknaan ontologis yang seperti itu, maka hukum tidak lain adalah peraturan-peraturan tertulis, seperti Undang-Undang dan lain sebagainya yang berbentuk teks. Kebenaran realitas dalam paradigma ini berposisi objektif terhadap subjeknya sebagaimana epistemologinya yang 'dualis/objektivis'. Semakin jauh jarak antara subjek dengan hukum tertulis, maka akan semakin objektif penegakan hukum yang dihasilkan. Hal ini cocok dengan apa yang terjadi pada kasus hukum Baiq Nuril. Hakim pada tingkat kasasi hanya menerapkan hukum tertulis sebagaimana adanya, menelusuri terbuktinya pasal yang didakwaan terhadap fakta-fakta perbuatan, tanpa memerhatikan konteks atau bebas konteks, bebas bias, dan objektif sebagaimana hukumnya.

Melalui kebenaran paradigma positivisme, apa yang terjadi pada kasus Baiq Nuril semestinya dapat dipahami dengan baik. Hakim sebagai penganut paradigma ini sedang menjalankan keyakinan atas kebenaran sebagaimana panduan paradigma tersebut, dan itu sah untuk dilakukan. Sementara ada kebenaran versi lain yang dihadirkan oleh penganut tiga paradigma yang lainnya.

Penganut paradigma post-positivisme mendasarkan pemaknaan realitas dengan ontologinya yang realisme kritis. Dalam hal ini, hukum dimaknai juga sebagai peraturan tertulis, namun dengan epistemologinya yang 'dualisme surut' maka subjek dalam hal ini kita atau dalam konteks penegakan hukum berarti penegak hukum dapat memberikan makna menurut rasa, hati nurani dan pikiran pribadi terhadap hukum yang tertulis itu. Maka jika penegak hukum dalam kasus Baiq Nuril ini adalah seorang post-positivist, maka Pasal 27 (1) UU ITE tidak semata-mata diterapkan begitu saja, tetapi dapat dimaknai dengan interpretasi terhadap teksnya. Bukan tidak mungkin, putusan yang dihasilkan hakim juga akan berbeda dengan kondisi existing.

Berbeda lagi dengan kebenaran yang dipandu paradigma critical theory et.al., realitas hukum dimaknakan sebagai realisme historis yang adalah realitas virtual yang dipengaruhi oleh faktor-faktor tertentu di sepanjang sejarah terbentuknya hingga kemudian dianggap real dan diterima benar. Padahal hukum adalah realitas yang senantiasa bersifat memihak kepada mereka yang berkuasa, menindas yang lemah, opresif, dan diskriminatif kepada mereka yang 
lemah, miskin, perempuan, dan kelompok tertindas. Dalam hal ini epistemologi critical theory et.al. adalah transaksional/subjektivis, atau realitas akan sangat bersifat subjektif bagi penganut critical theorist. Hal ini yang nyata berbeda dengan dua paradigma sebelumnya. Dalam telaah paradigma ini, penegak hukum dalam kasus Baiq Nuril justru akan melihat UU ITE sebagai produk hukum yang timpang dan menindas kepada mereka yang lemah, dalam hal ini Baiq Nuril yang sejatinya adalah korban pelecehan seksual. Jika hukum terpahami seperti ini, maka putusan bebas akan menjadi opsi terbaik dalam penjatuhan vonis berdasarkan alam berpikir paradigma ini.

Lain lagi dengan paradigma konstruktivisme. Realitas hukum dimaknakan sebagai realitas dengan sifatnya yang relatif sebagaimana ontologi paradigma ini. Dengan epistemologi yang juga 'transaksional/subjektivis', pemahaman terhadap hukum akan bersifat sangat subjektif tergantung subjeknya, berdasarkan pengalaman sosial individual masingmasing, lokal, dan spesifik. Dengan demikian, secara metodologis realitas hukum akan terwujud melalui penafsiran demi penafsiran yang sangat subjektif hingga kemudian dalam penyelesaian kasusnya membutuhkan suatu konsensus sebagai resultante kesepakatan dari pemikiran masing-masing pihak yang subjektif tersebut. Dengan alam berpikir seperti ini, semestinya kasus Baiq Nuril lebih mengedepankan proses dialektikal, musyawarah antarpihak untuk menyelesaikan solusi terbaik atas kasus hukum yang menimpa Baiq Nuril. Senada dengan proses tersebut, ketika di persidangan hakim juga dapat melakukan interpretasi penuh dengan hermeneutikal guna mencari keadilan hukum bagi pihak-pihak yang berperkara. Hakim dapat menggali nilai-nilai keadilan dan nilai lainnya yang sepenuhnya diakomodasi sebagai hukum yang ideal guna memberikan keadilan bagi Baiq Nuril.

Demikianlah kajian paradigmatik telah penulis sampaikan melalui telaah empat paradigma yang ada. Kajian tersebut semestinya dapat membuka ruang pemahaman bagi kita bahwa hakikat hukum tidaklah tunggal, setidaknya kita mengenal ada empat besar hakikat hukum sebagaimana terjabar dalam ontologi empat paradigma tersebut. Dengan demikian, kebenaran hukum juga tidaklah bersifat tunggal karena ada empat kebenaran yang terpampang dalam kebenaran masing-masing paradigma tersebut, bahkan lengkap dengan epistemologi dan metodologinya. Sudah seharusnya bagi kita kaum terpelajar yang mengenal tentang paradigma dapat tenang memahami setiap perbedaan pendapat yang ada terkait kasus hukum Baiq Nuril, untuk kemudian dapat menjelaskan secara komprehensif bahwa masing- 
masing pendapat yang ada tidak lahir begitu saja tanpa set basic belief dari paradigmanya masing-masing. Bahwa hebohnya kasus hukum Baiq Nuril ini sejatinya hanyalah persoalan cara berhukum yang berbeda yang berangkat dari pikiran kebenaran yang berbeda atau paradigma yang tidak sama, itu saja.

\section{KESIMPULAN}

Berdasarkan uraian sebelumnya, di akhir tulisan ini penulis akan menarik simpulan terhadap pembahasan kasus hukum Baiq Nuril sebagai berikut:

1. Bahwa putusan hakim pada tingkat kasasi terhadap Baiq Nuril adalah hasil daripada proses berpikir positivisme hukum yang memandu lahirnya cara berhukum yang objektif. Putusan pidana yang dijatuhkan hakim Mahkamah Agung sejatinya tidak salah dalam kerangka positivisme hukum.

2. Telaah filsafat hukum melalui kajian paradigma menunjukkan bahwa telaah pada satu peristiwa hukum, yakni kasus Baiq Nuril dalam hal ini akan menghasilkan analisis kebenaran yang berbeda. Terdapat empat paradigma dengan masing-masing ontologi, epistemologi, dan metodologinya menyajikan setidaknya juga empat kebenaran tentang hukum. Pada paradigma mana seseorang 'berkiblat', maka cara berhukumnya akan berbeda dan menghasilkan wujud konklusi berupa pikiran/pendapat/putusan yang berbeda.

\section{DAFTAR PUSTAKA}

Denzin, Norman K. \& Lincoln, Yvonna S.(ed). The Sage Handbook of Qualitative Research 1 Third Edition. Yogyakarta: Pustaka Pelajar, 2011.

Hantoro, Juli. "ICJR Pertanyakan Putusan MA dalam Kasus Baiq Nuril”, Tempo.Co, diakses dari https://nasional.tempo.co/read/1146060/icjr-pertanyakan-putusan-ma-dalam-kasus-baiqnuril, pada tanggal 14 November 2018.

Indarti, Erlyn. Diskresi dan Paradigma: Suatu Telaah Filsafat Hukum, Pidato Pengukuhan Guru Besar Universitas Diponegoro. Semarang: Badan Penerbit Undip, 2010.

Moleong, Lexy J. Metodologi Penelitian Kualitatif. Bandung: Remaja Rosdakarya, 2007.

Prasetyo, Teguh \& Barkatullah, Abdul Halim. Filsafat, Teori, dan Ilmu Hukum: Pemikiran Menuju Masyarakat yang Berkeadilan dan Bermartabat. Jakarta: Rajagrafindo Persada, 2013. 
Rato, Dominikus. Filsafat Hukum: Mencari, Menemukan, dan Memahami Hukum. Yogyakarta: LaksBang Justitia, 2010.

SAH dan ARH. "Kronologi Kasus Baiq Nuril", CNN Indonesia, diakses dari https://www.cnnindonesia.com/nasional/20181114133306-12-346485/kronologi-kasus-baiqnuril-bermula-dari-percakapan-telepon, pada tanggal 14 November 2018.

Samekto, Adji. Pergeseran Pemikiran Hukum dari Era Yunani Menuju Postmodernisme. Jakarta: Konstitusi Press, 2015.

Sulistyawan, AY. "Mempersoalkan Objektivitas Hukum: Suatu Perbincangan Filsafat Hukum”. Jurnal Masalah-Masalah Hukum Vol. 41, No. 4, Tahun 2012.

Wismabrata, Michael Hangga. "5 Fakta Baru Kasus Baiq Nuril: Muslim Tak Ngantor 4 Hari Hingga Nuril Diperiksa Polisi”, kompas.com, diakses dari https://regional.kompas.com/read/2018/11/24/14480891/5-fakta-baru-kasus-baiq-nurilmuslim-tak-ngantor-4-hari-hingga-nuril pada tanggal 24 November 2018. 